\title{
Student's Problem-Solving Skill on Momentum Conservation Law
}

\author{
$1^{\text {st }}$ Dina Prihartanti \\ SMK Negeri 1 Panggungrejo \\ Blitar Regency, Indonesia \\ Corresponding author: \\ dinaprihar@gmail.com
}

\author{
$2^{\text {nd }}$ Lia Yuliati \\ Physics Department, Faculty of \\ Mathematics and Natural Science \\ State University of Malang \\ Malang, Indonesia \\ liayuliati68@gmail.com
}

\author{
$3^{\text {rd }}$ Hari Wisodo \\ Physics Department, Faculty of \\ Mathematics and Natural Science \\ State University of Malang \\ Malang, Indonesia \\ hari.wisodo.mipa@um.ac.id
}

\begin{abstract}
Problem-solving skill is one of the competencies that must be achieved by vocational students. This study aimed to describe the problem-solving skill of students on the concept of momentum's conservation law. The participants of this study were 28 students of eleventh graders at SMK in Blitar in the academic year 2016/2017. The data description of student's problem-solving skill obtained through tests and interviews. Analysis data was performed by analyzing the test results of per item answer to questions. The results showed that the students' problem-solving skill was still less optimal, namely on the indicator of determining the strategy, applying the strategies and evaluating the solutions.
\end{abstract} law

Keywords - problem-solving, momentum conservation

\section{INTRODUCTION}

Problem-solving skill is one of the competencies that should be reached by the students, especially vocational students. The characteristic of vocational senior high school as one of the formal education is aiming at resulting in skillful, competitive, and ready to work students and demanding them to have skill in problem-solving. Problem-solving skill is beneficial to result in the innovative solution to face current and future world problems so that the problem -solving skill becomes one of basic standard competency that should be reached by $21^{\text {st }}$ century education [1]. According to Preseissen in Costa, problem-solving as one of the complex thinking processes needs a necessary thinking skill (causeeffect/transformation) to identify the problem, determine the alternative solution and test the feasibility, evaluate the solution, and generalize the solution [2]. The problemsolving skill includes some significant steps, for example, identifying the problem, determining the solving strategy, verifying the solution [3-6].

Plenty of previous research that tried to improve the problem-solving skill by using any learning strategies. One of the learning strategies used in the research is ProblemBased Learning [7], modelling learning by using metacognitive approach [8], learning through contextual and complex questions [9], interactive problem-solving learning assisted by computer [10], learning design of map setting by implementing the link maps [11-12], contextbased learning [13], conceptual problem solving [14], and problem-solving approach through students' reflection with their partners [15].

Problem-solving skill is closely related to the student's knowledge structure. In problem-solving, students need knowledge from the previous experience including learning and daily experiences [16]. Therefore, the students should be active in constructing specific knowledge/physics concept learned [17]. Some cognitive processes are needed to learn the conceptual knowledge and build the knowledge structure [18]. Based on the constructivist theory of learning, learning is not merely a knowledge transfer but also how to construct the knowledge by linking their prior knowledge with the new experience they get [19]. A deep knowledge is needed to activate the functional understanding that is reasoning capability in facing different problems and not based on the memory [17-18]. Due to the relationship between reasoning capability and problem-solving skill, it is essential for the teacher to give a learning design that can train the reasoning capability to be successful in problem-solving [4].

The fact shows that physics learning in Vocational High School tends to be a subject-oriented to exercises in the textbook and it mostly concerns doing calculating questions that only use formulation in calculating. Mazur in Jonassen states that many students are successful in finishing physics items by applying physics formulation in a mathematic procedure without knowing the concept underlying it [20]. Facing many items not always trains the functional understanding ability in the problem-solving $[17,18,20]$. The students should be habituated or trained to face new problems by a meaningful explanation to improve the problem-solving skill [18].

The characteristics of physics knowledge that is related to physics concepts become an individual problem for the students in understanding physics concept and building the physics knowledge structure, for example, for the topic of impulse and momentum [21-22]. The previous research mostly discussed the students' difficulties in applying the concept in the topic of impulse and momentum to the daily problems [23-27]. The students were low in connecting the physics understanding with the application in the daily facts; for instance, the students were wrong in interpreting the momentum and kinetic energy of the objects clashing because they did not link the theory of momentum impulse and energy effort theory in the clashing demonstration [23]. The students' difficulty in understanding the momentum as a vector magnitude related to momentum conservation [22, 27]. The students are difficult in interpreting the concept of momentum and energy qualitatively applied in the daily physics problems [25-26]. The student's difficulties in understanding the physics concept give an implication that 
physics learning that can develop the functional understanding of the new concept through experiment or direct observation is urgently needed [17]. The use of video/film can also make the students learn the science easily [28].

Based on the explanation above, constructivist learning that can train the students to activate the functional understanding in problem-solving is needed to improve their problem-solving skill. The previous research showed that map meetings learning including summary lecture, problem-solving session, and the plenary could help the novice students in understanding the physics concept and develop the problem-solving skill [11]. Therefore, this research was conducted to describe the problem-solving skill on the concept of impulse, momentum, and theory of momentum impulse by using map meetings learning design.

\section{METHODS}

Research by using mixed methods approach of this embedded experimental model was conducted in October 2016 to 28 eleventh graders of Competency and Expertise of Light Vehicle Engineering of SMKN 1 Panggungrejo The academic year of 2016/2017. The learning design applied in this research was map meeting consisting of the steps summary lecture, problem-solving session, and the plenary. The collected data were in the form of students' answers in doing the items of the concept of impulse, momentum, and theory of momentum impulse. The data collecting technique was in the form of test before and after the intervention, quiz, and exercise in the discussion of problem-solving. The data on students' answers were analyzed based on the indicator criteria of the problemsolving skill of IDEAL from Brandsford and Stein including the ability to identify the problem, defining and representing the problem, exploring the possible strategies, the act on strategies, and the ability to evaluate the solution (look back and evaluate the effect of your activities). The result of analysis of students' answers was confirmed by using the data of interview results and presented in the form of narrative, picture, and table. From all data of the tests and interview results were then interpreted to be concluded.

\section{RESULTS}

The student's problem-solving skill on the concept of momentum conservation is described from the analysis of students' answers in the discussion of the problem-solving session, the quiz answer and the answer of pre-test and posttest. There were two description questions explained in the discussion of problem-solving, one question in the quiz, and one question of pre-test and post-test.

\section{Description of Student's Problem-Solving on the Question of Problem-Solving Session}

The question described in the learning for the problemsolving session and on the concept of Momentum Conservation Law was about recoil. The questions finished were in the form of conceptual and calculation questions.

Description of the Analysis Results of Student's Problem Solving Skill in the Problem Solving Session in the Form of Conceptual Question

There were two questions done in this step presented in Fig. 1. The question number 1 is about recoil surge of the gun when a bullet shoots by the shooter, and students should explain why the gun recoil is not more dangerous if compared to shot by a bullet. While question number 2 was about unstable hose tip movement when the faucet was opened maximally, students should to explain about this phenomenon and give solution how to make hose, but the water still can flow swiftly. The analysis result of student's problem-solving skill in the problem-solving session about the concept of momentum conservation law is described in Table 1 .

(1) Seorang penembak jitu pasukan militer menembakkan peluru dengan menempelkan ujung belakang senapannya pada bahu. Jika momentum ke depan peluru sama dengan momentum ke belakang dari senapan, mengapa terkena sentakan ke belakang dari senapan tidaklah lebih berbahaya jika dibandingkan dengan tertembak peluru?

(2) Pada saat hendak mencuci sepeda motor, Roni menghubungkan selang air dengan kran. Ketika kran dibuka maksimal, air mengalir cukup deras dan ujung selang bergerak tidak stabil. Jelaskan analisismu tentang kejadian inil Apakah yang harus dilakukan Roni agar ujung selang kembali stabil namun air tetap dapat mengalir dengan deras?

Fig. 1. The Question of Problem-Solving Session on the Concept of Momentum Conservation Law 
Based on the analysis of students' answers (Table 1) for the question given in the problem-solving session, the students' problem-solving skill was still less. In case of recoil of the shotgun, most of the students could identify the problem but less completely (A3 level), in the indicator of defining the problem, most of the students could mention the relevant information although it was lack of completeness (B3 level). In the indicator of determining the strategy, the students were less suitable for determining the physics concept (C2 level). In the indicator of applying the strategy, most of the students could explain the solution based on the physics concept although the explanation given was less clear and less connected logically; the explanation given was still fragmented (E2 level). Meanwhile, for the case of the motion of the hose tip, most of the students showed the low skill that was level 2 for all indicators. Based on the analysis of students' answers, we can conclude that the students were still low in applying the strategy and evaluating the solution. The examples of students' answers to the discussion questions are presented in Fig. 2. For the question number 1, student's answer is No, because the gun and the bullet have a different mass so that when the bullet was shot, the speed of the bullet and the gun is different, the mass of the gun is more significant than the mass of the bullet. While the student was answering or inquiry number 2 is Roni must give momentum to the hose with the same suppression to the water flowing from the hose.

Table 1. Description of Students Problem-Solving Skill in the Problem-Solving Session of Momentum Conservation Law

\begin{tabular}{|c|c|c|c|c|c|c|c|}
\hline \multirow{2}{*}{\multicolumn{2}{|c|}{ No. Indicator }} & \multirow{2}{*}{$\begin{array}{c}\text { Problem-Solving Skills } \\
\text { Indicator } \\
\end{array}$} & \multicolumn{5}{|c|}{ Percentage Number of Students (\%) } \\
\hline & & & CODE & 4 & 3 & 2 & 1 \\
\hline \multirow[t]{5}{*}{1.} & \multirow{5}{*}{$\begin{array}{l}\text { Using momentum } \\
\text { conservation law to } \\
\text { solve the problems } \\
\text { related to recoil } \\
\text { phenomena.(the case of } \\
\text { shotgun air) }\end{array}$} & Identify the problems & $\mathbf{A}$ & 17,86 & 42,86 & 25 & 14,29 \\
\hline & & Define the problems & $\mathbf{B}$ & 10,71 & 46,43 & 42,86 & 0 \\
\hline & & $\begin{array}{c}\text { Explore the possible } \\
\text { strategies } \\
\end{array}$ & $\mathbf{C}$ & 7,14 & 32,14 & 60,71 & 0 \\
\hline & & Act on Strategies & $\mathbf{D}$ & 7,14 & 57,14 & 35,71 & 0 \\
\hline & & $\begin{array}{c}\text { Look back and evaluate the } \\
\text { solution } \\
\end{array}$ & $\mathbf{E}$ & 3,57 & 28,57 & 64,29 & 3,57 \\
\hline \multirow[t]{5}{*}{2.} & $\begin{array}{l}\text { Using momentum } \\
\text { conservation law to }\end{array}$ & Identify the problems & $\mathbf{A}$ & 35,71 & 0 & 64,29 & 0 \\
\hline & $\begin{array}{l}\text { related to recoil } \\
\text { phenomena. (the case of }\end{array}$ & Define the problems & B & 17,86 & 25,00 & 57,14 & 0 \\
\hline & water hose). & $\begin{array}{c}\text { Explore the possible } \\
\text { strategies }\end{array}$ & $\mathbf{C}$ & 0 & 17,86 & 82,14 & 0 \\
\hline & & Act on Strategies & $\mathbf{D}$ & 0 & 17,86 & 71,43 & 10,71 \\
\hline & & Look back and evaluate the & $\mathbf{E}$ & 7,14 & 10,71 & 71,43 & 10,71 \\
\hline
\end{tabular}

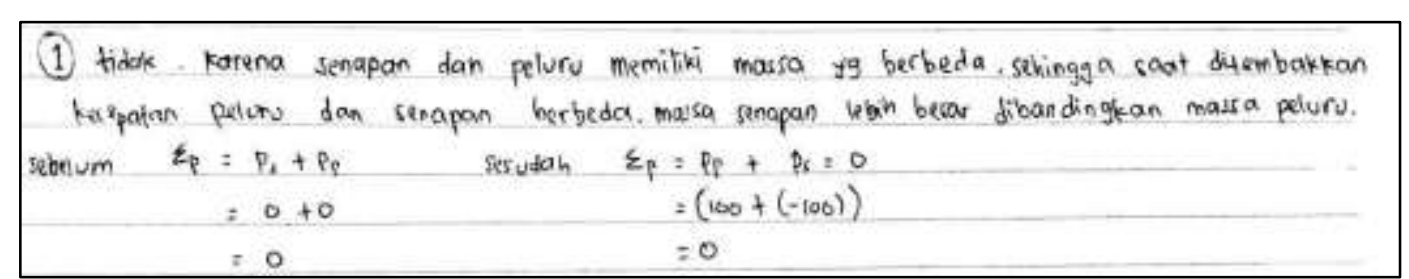

(a)

2. Roni harus momberikan momentum pada selang dengan tekanan jang sama pada air
yang keluar dari selang

(b)

Fig. 2. (a) Example of Students' Answers to the Question Number 1 (b) Example of Students' Answer to the Question Number 2 


\section{Description of Analysis Result of Student's} Problem-Solving Skill in the Problem-Solving Session in the Form of Calculation Question

There was one question in the problem-solving session, the application of momentum conservation law in the form of calculation item as presented in Fig. 3. This question is about a fisherman that rides a ship moving at the speed of $4 \mathrm{~m} / \mathrm{s}$, the mass of the fisherman is $60 \mathrm{~kg}$, and the mass of the ship is $80 \mathrm{~kg}$.
Suddenly, the net is snagged to stone, so that he must jump into the water with the opposite direction with the ship move. If the fisherman jumps at the speed of $2 \mathrm{~m} / \mathrm{s}$, students should calculate how much the speed of the ship right after the fisherman jumps. The analysis result of student's problem-solving skill in the problem-solving session about the concept of momentum conservation law for the calculation question was described like presented in Table 2.

(2) Seorang nelayan menaiki perahu yang bergerak dengan kecepatan $4 \mathrm{~m} / \mathrm{s}$. Massa nelayan $60 \mathrm{~kg}$ dan massa perahu $80 \mathrm{~kg}$. Tiba-tiba jaringnya tersangkut batu, sehingga ia harus melompat ke dalam air dengan arah berlawanan gerak perahu. Jika nelayan melompat dengan kecepatan $2 \mathrm{~m} / \mathrm{s}$, berapakah kecepatan sesaat perahu sesudah nelayan melompat?

Fig. 3. The question in Problem-Solving Session on the Concept of Momentum Conservation Law in the Form of Calculation Question

Table 2. Description of Student's Problem-Solving Skill on the Question in Problem-Solving Session about the Application of the Concept of Momentum Conservation Law in the Form of Calculation Question

\begin{tabular}{|c|c|c|c|c|c|c|}
\hline \multirow[t]{2}{*}{ Indicator } & \multirow{2}{*}{$\begin{array}{c}\text { Problem-Solving Skills } \\
\text { Indicator }\end{array}$} & \multicolumn{2}{|c|}{ Percentage } & \multicolumn{3}{|c|}{ Number of Students (\%) } \\
\hline & & CODE & 4 & $\mathbf{3}$ & 2 & 1 \\
\hline \multirow{5}{*}{$\begin{array}{l}\text { Using momentum conservation } \\
\text { law in problem-solving } \\
\text { (identifying the problem, } \\
\text { defining the problem, } \\
\text { determining the strategy, } \\
\text { applying the strategy, } \\
\text { evaluating the solution) for the } \\
\text { case of clashing in the form of } \\
\text { calculation. }\end{array}$} & Identify the problems & A & 32,29 & 10,71 & 28,57 & 21,43 \\
\hline & Define the problems & $\mathbf{B}$ & 10,71 & 39,29 & 50 & 0 \\
\hline & Explore the possible strategies & C & 7,14 & 75 & 17,86 & 0 \\
\hline & Act on Strategies & $\bar{D}$ & 32,14 & 46,43 & 21,43 & 0 \\
\hline & $\begin{array}{l}\text { Look back and evaluate the } \\
\text { solution }\end{array}$ & $\mathbf{E}$ & 21,43 & 50 & 17,86 & 10,71 \\
\hline
\end{tabular}

Based on the analysis of students' answers (Table 2) to the question given in problem-solving session in the form of calculation question, the students' problem-solving skill seemed good enough if it was compared to the conceptual question. For the indicator of identifying the problem, most of the students were at level 4 (A4). For the indicator of defining the problem was at level 2 since most of the students did not write down the complete information. Meanwhile, for the other three indicators such as determining the strategy, applying the strategy, and evaluating the solution, most of the students were at level 3. The example of student' answer for the question of momentum conservation law in the form of calculation is presented in Fig. 4.

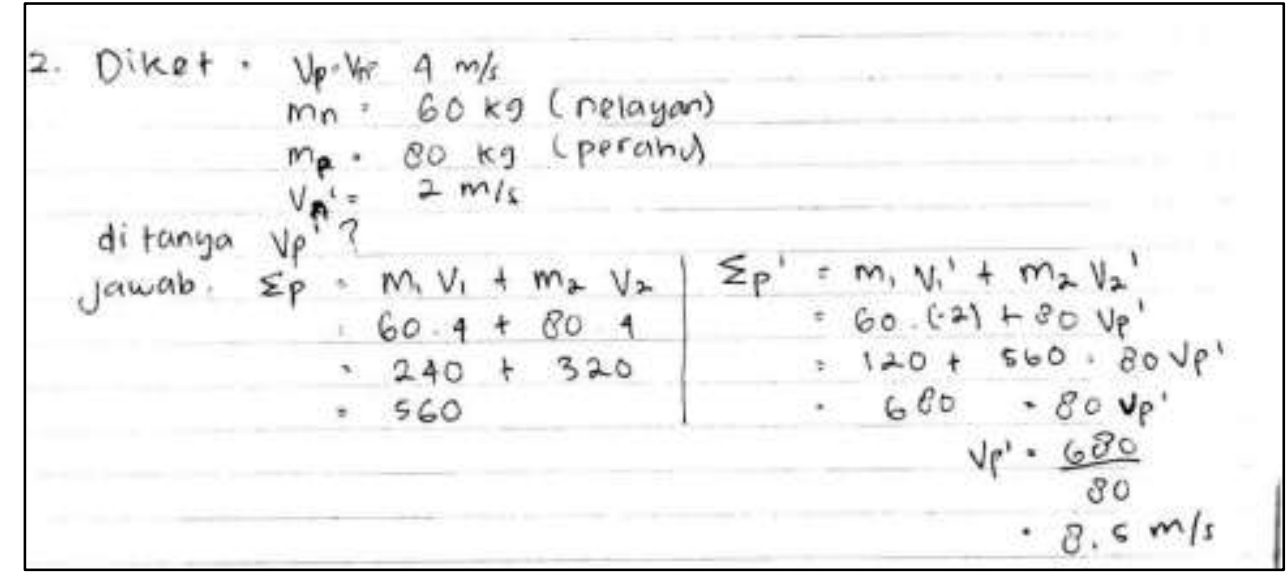

Fig. 4. Example of Student's Answer of Question in Problem-Solving Session about Concept of Momentum Conservation Law in the Form of Calculation Item 
Based on the result of interviews with students, the help of link maps given in the discussion could not be used by all students optimally for the conceptual question. Not all students could use link maps when answered the question; some students mentioned that link maps helped them especially for calculation items. The students still got difficulty to connect the concept of momentum conservation law in solving the daily problems.

\section{Description of Student's Problem-Solving Skill on the Quiz Question}

The problem-solving skill in applying the concept of momentum conservation law was also analyzed from the answer of the quiz. The question given in the quiz was determining whether the throw of clay sticking to the wall violates the momentum conservation law as shown in Figure 5 (a). The example of student's answer for the quiz question is presented in Figure 5 (b). The analysis result of student's problem-solving skill on the quiz question about the concept of momentum conservation law is described in Table 3.

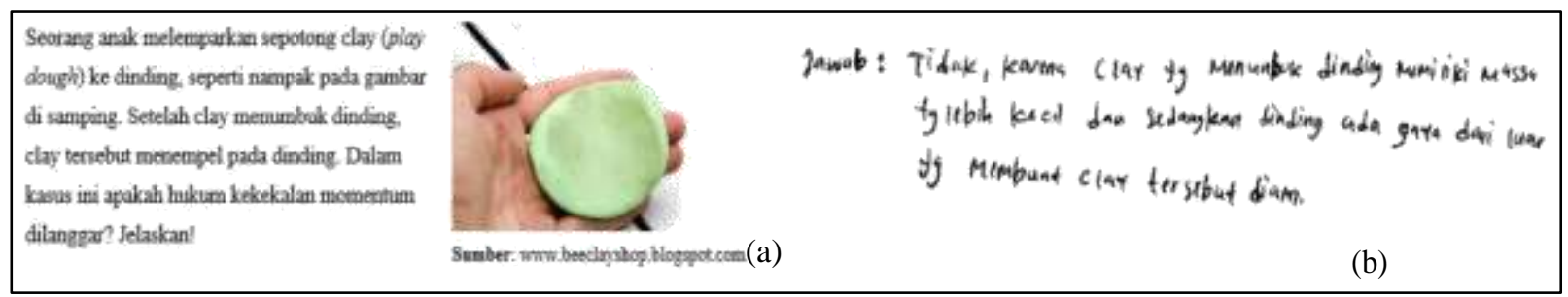

Fig. 5. (a) The quiz question of the concept of momentum conservation law; (b) The example of student's answer to the quiz question of the concept of momentum conservation law

Table 3. Description of Students Problem-Solving Skills on Quiz of Momentum Conservation Law

\begin{tabular}{|c|c|c|c|c|c|c|}
\hline \multirow{2}{*}{ Indicator } & \multirow{2}{*}{$\begin{array}{c}\text { Problem Solving Skills } \\
\text { Indicator }\end{array}$} & \multicolumn{5}{|c|}{ Percentage Number of Students (\%) } \\
\hline & & \multicolumn{2}{|c|}{ CODE4 } & \multirow{2}{*}{89,29} & \multirow{2}{*}{$\begin{array}{l}2 \\
10,71\end{array}$} & \multirow{2}{*}{1} \\
\hline Using the momentum & Identify the problems & $\mathbf{A}$ & 0 & & & \\
\hline $\begin{array}{l}\text { conservation law in problem- } \\
\text { solving (identifying the }\end{array}$ & Define the problems & B & 0 & 78,57 & 21,43 & 0 \\
\hline problem, defining the & Explore the possible strategies & $\mathbf{C}$ & 0 & 35,71 & 60,71 & 3,57 \\
\hline problem, determining the & Act on Strategies & D & 0 & 14,29 & 85,71 & 0 \\
\hline $\begin{array}{l}\text { evaluating the solution) for the } \\
\text { case of clashing. }\end{array}$ & $\begin{array}{l}\text { Look back and evaluate the } \\
\text { solution }\end{array}$ & $\mathbf{E}$ & 0 & 7,14 & 78,57 & 14,29 \\
\hline
\end{tabular}

Based on Table 3, we can see that most of the students could identify the problem and define it well. However, the given explanation still did not show the analysis using momentum conservation law like the example of student's answer in Fig. 5 (b). The student only mentioned the difference of mass between the clay and wall and they did not explain the concept of the momentum of both objects.

\section{Description of Student's Problem-Solving Skill on the Question in Pre-Test and Post-Test}

Based on the result of pre-test and post-test for the concept of momentum conservation law, we can know that the student's problem-solving skill changed better than before. The question done in pre-test and post-test for such topic is mentioned in Fig. 6. The question is about four wagon with the similar mass that is coupling each other but quickly released, and it is pushed to move in $\mathrm{v}$ speed. Unfortunately, these wagons move on the wrong track that leads to the broken bridge. Students must provide solutions how can the wagon move in opposite directions so that the miner who is in the rear wagon can be safe. The example of student's answer in the pre-test is presented in Fig. 7 (a) the answer in post-test is presented in Fig. 7 (b). The student's answer is presented in Fig. 7 (a) show that students did not give solutions and just rewrite the question, whereas the student's answer in post-test (Fig. 7 b) shows that students give solutions by answering that the miner who rides on the mining 
train must put off the wagon the first. Then, the wagons from the front part and push the wagon pushed forward off so that the wagon which he rides on moves in the opposite direction/moves backward, so the mining train will be slow down/moves in the opposite direction. The description of student's problemsolving skill on the concept of momentum conservation law for the question in pre-test and posttest is shown in Table 4.

Based on Table 4, we can know that generally, the student's problem-solving skill for each indicator has improved. For the skill of identifying problem, when pre-test, most of the students could not be able to identify the problem correctly $(60,71 \%)$. The students tended to determine how to make the train was not wrong in the line. When post-test, most of the students $(50 \%)$ could be able to identify the problem correctly although they did not mention explicitly that was determining how does a train become slow or move. For the indicator of identifying the problem in the pretest, many students $(53.57 \%)$ who mentioned irrelevant information such as emergency brake and reducing the fuel. In post-test, the student could be able to mention the critical and relevant information although there were some of them who answered less thoroughly. For the indicator of determining the strategy and applying the strategy, when pre-test, $75 \%$ of the students had not shown the strategy based on physics concept; they determined the solution based on the logic and information of the question. However, in post-test, $53.57 \%$ of the students seemed to be able to explain and determine the solution based on the momentum conservation law. From the sequence of the students' sentences of their answers, we can see that the students' ability to evaluate the solution in pretest was 60.717 of the students who gave unclear and illogical sentences. However, in post-test, there was a better change although only $3.57 \%$ of the students who could give an answer clearly which was focused and correlated logically; $64.29 \%$ of the students gave less precise and less logical answers and only $7.14 \%$ of the students who gave answers with all sentences which were unclear and illogical.

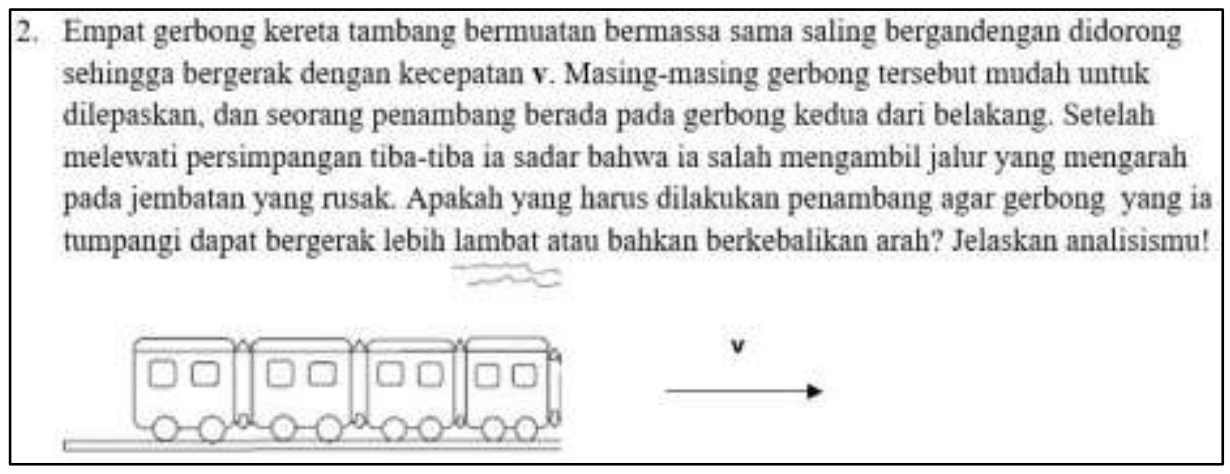

Fig. 6. Question of Pre-Test and Post-Test regarding Momentum Conservation Law

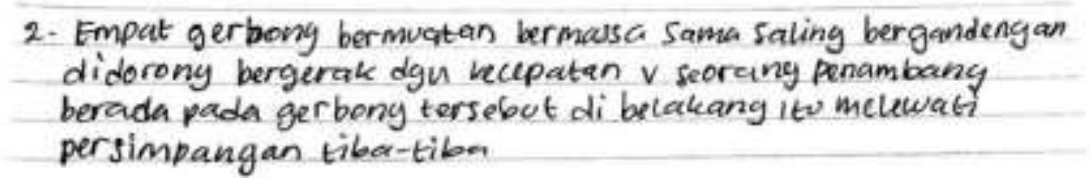

(a)

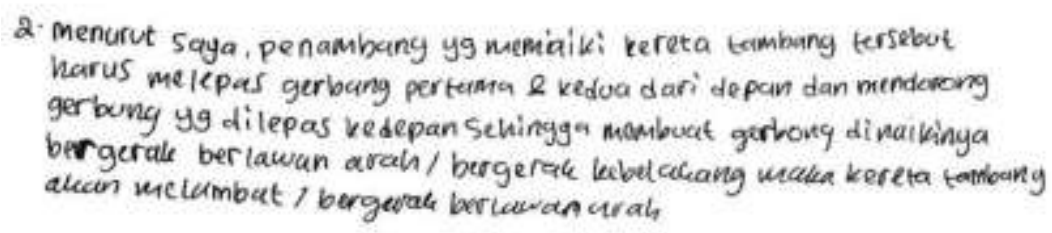

(b)

Fig. 7. (a). Example of Student's Answer in Pre-Test; (b) Example of Student's Answer in Post-Test 
Table 4. Description of Student's Problem-Solving on the Question in Pre-Test and Post-Test Regarding Momentum Conservation Law

\begin{tabular}{|c|c|c|c|c|c|c|c|}
\hline \multirow{2}{*}{ Indicator } & \multirow{2}{*}{$\begin{array}{c}\text { Problem Solving Skills } \\
\text { Indicator }\end{array}$} & \multirow{2}{*}{$\begin{array}{c}\text { Problems } \\
\text { on }\end{array}$} & \multicolumn{5}{|c|}{ Percentage Number of Students $(\%)$} \\
\hline & & & CODE & 4 & 3 & 2 & 1 \\
\hline \multirow{10}{*}{$\begin{array}{l}\text { Using momentum } \\
\text { conservation law in } \\
\text { solving the problem } \\
\text { (identifying the } \\
\text { problem, defining the } \\
\text { problem, determining } \\
\text { the strategy, applying } \\
\text { the strategy, evaluating } \\
\text { the solution) for the } \\
\text { recoil phenomenon. }\end{array}$} & \multirow{2}{*}{ Identify the problems } & Pre-test & \multirow{2}{*}{$\mathbf{A}$} & 0 & 25,00 & 60,71 & 14,29 \\
\hline & & Post-test & & 32,14 & 50,00 & 17,86 & 0 \\
\hline & \multirow{2}{*}{ Define the problems } & Pre-test & \multirow{2}{*}{ B } & 0 & 17,86 & 28,57 & 53,57 \\
\hline & & Post-test & & 25,00 & 50,00 & 17,86 & 7,14 \\
\hline & \multirow{2}{*}{$\begin{array}{c}\text { Explore the possible } \\
\text { strategies }\end{array}$} & Pre-test & \multirow{2}{*}{$\mathbf{C}$} & 0 & 10,71 & 14,29 & 75,00 \\
\hline & & Post-test & & 10,71 & 53,57 & 32,14 & 3,57 \\
\hline & \multirow{2}{*}{ Act on Strategies } & Pre-test & \multirow{2}{*}{$\mathbf{D}$} & 0 & 17,86 & 14,29 & 75,00 \\
\hline & & Post-test & & 3,57 & 42,86 & 50,00 & 3,57 \\
\hline & \multirow{2}{*}{$\begin{array}{l}\text { Look back and evaluate the } \\
\text { solution }\end{array}$} & Pre-test & \multirow{2}{*}{$\mathbf{E}$} & 0 & 17,86 & 21,43 & 60,71 \\
\hline & & Post-test & & 3,57 & 25,00 & 64,29 & 7,14 \\
\hline
\end{tabular}

Quantitatively, the mean score of the students in pre-test and post-test increased 37.95; from the mean score of pretest which was 20.89 changed to 58.84 in post-test. The calculation of N-gain on the mean score of pre-test and posttest got the score of 0.48 meaning that the improvement of student's problem-solving skill on the concept of momentum conservation law was categorized as moderate.

\section{DISCUSSION}

The analysis result of student's answer to the question in problem-solving session about the concept of momentum conservation law showed the student's problem-solving skill which was relatively low in determining strategy, applying the strategy, and evaluating the solution on the new conceptual questions for the students. The physics concept used was still relatively improper. For example, for the case of recoil surge of a harmless gun, the students answered that it was harmless due to the mass difference. Although the students wrote down the equation of the summation of before momentum and after momentum, the big difference between the gun surge speed with the bullet was unexplained regarding the mass difference. Therefore, the students' answers did not give a complete explanation about the correlation between the danger of the gun recoil surge based on the momentum conservation law. The similar thing also happened in the case of determining the way to make the tip of the hose became stable when the water was flown swiftly. Some students stated that the tip of the hose should be given momentum with the similar suppression on the water. The students' answer showed the less correct and less complete explanation regarding the momentum conservation law. The term of giving momentum is relevant if we state giving the external force. For the system consisting of hose and water, the unstable motion of the hose tip was due to the swift flow of the water. This case is based on the momentum conservation law stating that the number of the momentum of the hose tip and the water flow after the faucet is opened should be similar to the number of momentum number before the faucets are opened which is zero. Therefore, the external force for the hose tip should be given, and it is minimally proportional to the momentum change of the hose tip. Based on the answer given by the student, the students seemed did not give a correct explanation based on the momentum conservation law. The students' explanation showed the incomplete knowledge structure and the concepts that did not correlate with each other; whereas, broad conceptual knowledge is necessary for problem-solving [16]. The typical research result was also reported by Ivowi stating that most of the students could not be able to apply the principle of conservation law [29].

The weakness of problem-solving skill for the indicator of applying the strategy can also be seen from the analysis result of the students' answers in the quiz session. The less in-depth explanation which did not focus on the problem tended to happen in the problem-solving process done by the students. For instance, in case of clay thrown into the wall, the students did not focus on analyzing the condition before and after the clashing moment based on the momentum conservation law. Most of the students explained that the wall had an external force so that the clay could stick to the wall. This case was relevant to the previous research result reporting that the students were hard to understand the momentum conservation law and define the system [22]. Besides, the time of doing the quiz items was limited, and it became the factor of the lack of success in problem-solving. In the problem-solving process, the students need enough 
time to think, analyze, and try to solve the problem [30].

The student's problem-solving skill on the calculation question showed an excellent enough problem-solving skill of the students compared to the conceptual question. The students could give the correct answer although there were some of them who were less meticulous in writing the denomination. This case showed that the students felt easier in doing mathematical problem than the conceptual problem. Based on the questionnaire data before the intervention, it was found that the students were not used to finish the physics questions in the form of calculation and they tended to repeat the exercise in the textbook. This case is matched with the previous research indicating that to improve the problemsolving skill, and the students should be habituated or trained to face a new problem with a meaningful explanation [16]. Facing many items do not always train the functional understanding ability in problemsolving [16]; [17]; [20]. In-Depth knowledge is also needed to activate the functional understanding to solve the problem for the different situation [16-17].

Correlating the physics concept to the problem faced and applied it to find a solution are the activities for the indicator of applying the strategy that becomes the core of problem-solving activity. The result of this research showed that the students could not be able to activate the practical understanding. This case is relevant to the previous research result reporting that the students got difficulty in interpreting the concept qualitatively related to the energy and momentum applied in the real situation [23,25]. Although the students' analysis was less thorough and complete, the students could be able to answer directly to a correct solution. This case is matched with the previous research stating that the students got benefit in constructing a new knowledge from a real learning experience [31].

The student's problem-solving skill on the concept of momentum conservation law showed the improvement between before and after the intervention. Such improvement happened to all indicators such as identifying the problem, defining the problem, determining the strategy, applying the strategy, and evaluating the solution. However, the improvement happened to the indicator of applying the strategy and evaluation the solution was still less optimal, and the most of the students indicated this case was at level 3 and 2 for these particular indicators. The analysis of the student's answer showed that they were less able to apply the concept of momentum conservation law in solving the daily physics problems. This fact was supported with a written interview result (questionnaire) in which we found that the students were still used to face physics questions in the form of calculation and to emphasize on the concept application on the daily problems. The problem solving oriented to the use of the formulation for the mathematical questions did not show the students' understanding of the concept used. [20].

The student's lack of skill in applying the strategy and evaluating the solution was possibly due to their low understanding of the concept of momentum conservation law, or they were hard to correlate the concept learned to the problem faced. The interview results showed that not all students could use the help of link maps when they did the question. Some students mentioned that the link maps helped them in calculation question. This case showed that the students could not be able to interpret the physical meaning of physics equation and they only saw it as a mathematical equation so that they were difficult to connect the concept with the daily conceptual problems. The students see the physics equation as only a mathematical equation [32].

\section{V" CONCLUSION}

The student's problem-solving on the concept of momentum conservation law was still less optimal for the indicator of applying the strategy and evaluating the solution. The students' less understanding caused this case to the concept, and they were not used to face the contextual and conceptual questions. They were still lack of activating the functional understanding of problem-solving. Some alternatives can be done to make the students more experts in solving the problem, especially in physics learning such as habituating the students with the activity of constructivist learning to make the concept understood by the students more structuralized and more thorough. The students are needed to be habituated to face contextual questions and train the reasoning ability by applying the concept so that they not only apply the formulation based on their memory but also they have a complicated thinking process. The students are needed to be habituated to understand the physical meaning of the physics equation rather than only remember the mathematical formulation

\section{REFERENCES}

[1] The Partnership for 21st Century Skills, The MILE Guide: Milestones for Improving Learning and Education (2009).

[2] B. Z. Presseisen, Thinking Skills: Meanings and Models. Dalam Costa, A.L (Ed), Development Minds: A Resource Book for Teaching Thinking (pp.43-48). (The Association for Supervision and Curriculum Development, United States of America, 1985).

[3] S. M. Brookhart, How to Assess Higher-Order Thinking Skills in Your Classroom (ASCD, United States of America, 2010). 
[4] J. Carson, A problem with Problem Solving: Teaching Thinking without teaching Knowledge. The mathematic Educator vol. 17 No. 2, pp 7-14 (2007).

[5] P. Heller, R. Keith, S. Anderson, Teaching Problem solving Through Cooperative Grouping, Part 1. American Association of Physics Teachers, 60(7) pp.627-636 (1992).

[6] S. Krulik, and J. A. Rudnick, 1987. Problem Solving: A Handbook for Elementary School Teachers. (Allyn and Bacon, Boston, 1987)

[7] M. C. Lohman and M. Finkelstein, Designing Groups In ProblemBased Learning, To Promote Problem-Solving Skill And SelfDirectedness. Instructional Science, 28: pp. 291-307 (2000).

[8] K. L. Malone, Correlation among Knowledge Structures, Force Concept Inventory, and Problem-Solving Behaviors. Physical Review Special Topics-Physics Education Research. 4, 020107 (2008).

[9] C. A. Ogilvie, Change in Students' Problem-Solving Strategies in a Course that Includes Context-Rich, Multifaceted Problems. Physical Review Special Topics-Physics Education Research. 5, 020102 (2009).

[10] C. Singh, Problem Solving, and Learning. (Department of Physics and Astronomy University of Pittsburgh, Pennsylvania, 2009).

[11] C. Lindstrom and M. D. Sharma, Link maps and map meetings: Scaffolding student learning. Physical Review Special TopicsPhysics Education Research (5) (2009).

[12] C. Lindstrom and M. D. Sharma, Teaching Physics Novices at University: A case stronger scaffolding. Physical Review Special Topics-Physics Education Research 7, 010109 (2011).

[13] K. Y, Chao. S. C, Fan and K. Y, Lin, Enhancing Students' ProblemSolving Skills Through Context-Based Learning. International Journal of Science and Mathematics Education (2015)

[14] J. L. Docktor, N. E. Strand, J. P. Mestre, and B. H. Ross, Conceptual Problem Solving in High School Physics. Physical Review Special Topics-Physics Education Research 11 (2015).

[15] A. Mason and C. Singh, Helping Students Learn Effective Problem Solving Strategies By Reflecting With Peers. (Department of Physics and Astronomy University of Pittsburgh, Pittsburgh, 2016).

[16] B. Hegde, How do they solve it? An insight into the learner's approach to the mechanism of physics problem-solving. Physical Review Special Topics-Physics Education Research 8 (2012).

[17] L. C. McDermott, Students' Conceptions And Problem Solving In Mechanics. (Department of Physics, University of Washington, Seattle, Washington U.S.A, 2009).
[18] J. W. Gerace, Problem Solving, and Conceptual Understanding. Massachusetts: Physics Departement and Scientific Reasoning Research Institute (2001).

[19] R. I. Arends, Learning To Teach 9th edition. (McGraw-Hill, New York, 2012).

[20] D. H. Jonassen, Learning to Solve Problems. (John Wiley and Sons, Inc United States of America, 2004).

[21] F. Reif and J. I. Heller, Knowledge Structure and Problem Solving in Physics. Educational Psychologist: Vol. 17, No. 2, pp.102-127 (1982).

[22] T. G. K. Bryce and K. MacMillan, Momentum and Kinetic Energy: Confusable Concepts in Secondary School Physics. Journal of Research in Science Teaching. Vol. 46, No. 7, pp. 739-761 (2009).

[23] L. C. McDermott and R.A. Lawson, Student Understanding of The Work-Energy and Impulse-Momentum Theorems. American Journal of Physics (1987).

[24] T. O. Pride, S. Vokos, and L. C. McDermott, The Challenge of Matching Learning Assessments to Teaching Goals: An Example from The Work-Energy and Impulse-Momentum Theorems. American Journal of Physics (1998).

[25] C. Singh, C and D. Rosengrant, Student's Conceptual Knowledge of Energy and Momentum. Proceedings of The Physics Education Research Conference, pp.123-126 (2001).

[26] C. Singh, C and D. Rosegrant, Multiple-Choice Test Of Energy and Momentum Concepts. American Journal of Physics (6) (2003).

[27] H. G. Close and P. R. L. Heron, Research as A Guide for Improving Student Learning: An Example from Momentum Conservation. American Journal of Physics (2010).

[28] C. Efthimiou, and R. A. Llewellyn, Cinema as a tool for science literacy. Physics Education, 16(1), pp 1-13 (2004).

[29] Ivowi, U. M. O. Students' misconceptions about conservation principles and fields. Re- search in Science \& Technological Education, 4(2), 127-137. (1986).

[30] Hobri, Model-model Pembelajaran Inovatif. (Center for Society Studies, Jember, 2009).

[31] N. R. Ergul, Momentum Concept in the Process of Knowledge Construction. Educational Sciences: Theory \& Practice 13(3) pp. 1897-1901 (2013)

[32] B. Sherin, How Students Understand Physics Equation. Cognition and Instruction. 19(4), 479-541. Lawrence Erlbaum Associates, Inc (2001). 